Rafał Szczepaniak

\title{
Smog a odpowiedzialność odszkodowawcza władz publicznych
}

\author{
Smog and the tort liability of public authorities
}

According to the author, the civil law regime of tort liability of the state and other public authorities cannot be used to claim damages from the state for living in polluted air. Polluted air is a mass problem. The civil law classic mechanism of tort liability is not adapted to this kind of mass phenomena. In the author's opinion, such a conclusion stems from the principle of equality of citizens against public burdens. The author believes that this principle is the most important basis for the tort liability of the state. Moreover, he draws attention to various types of aberrations in the shape of the state liability regime, which arise as a result of the CJEU's case law.

Keywords: environmental protection, tort liability of public authorities

Autor artykułu stwierdza, że cywilnoprawny reżim odpowiedzialności deliktowej państwa i innych władz publicznych nie może być zastosowany w dochodzeniu odszkodowania od państwa za życie w zanieczyszczonym powietrzu. Problem zanieczyszczonego powietrza ma charakter masowy. Cywilnoprawny, klasyczny mechanizm odpowiedzialności odszkodowawczej nie jest przystosowany do tego rodzaju zjawisk masowych. Zdaniem autora wniosek taki płynie z zasady równości wobec ciężarów publicznych. Uważa on, że zasada ta jest podstawą odpowiedzialności deliktowej państwa. Zwraca również uwagę na różnego rodzaju aberracje, które dotyczą kształtu reżimu odpowiedzialności odszkodowawczej państwa, a które powstają na skutek orzecznictwa Trybunału Sprawiedliwości UE.

Słowa kluczowe: ochrona środowiska, odpowiedzialność deliktowa władz publicznych

doktor hab. nauk prawnych, prof. UAM -

Uniwersytet im. Adama Mickiewicza w Poznaniu, Wydział Prawa i Administracji, Katedra

Prawa Cywilnego, Handlowego i Ubezpieczeniowego, POZNAŃ, POLSKA •

rafal.szczepaniak.radcaprawny@gmail.com • https://orcid.org/0000-0001-6909-4912

\section{Wprowadzenie}

W środkach masowego przekazu można $\mathrm{w}$ ostatnich miesiącach coraz więcej usłyszeć o wytaczanych procesach odszkodowawczych, a nawet zasądzanych wyrokach, przeciwko państwu za szkody (krzywdy) powstałe w wyniku oddychania zanieczyszczonym powietrzem. Celem tego artykułu jest odpowiedź na pytania, czy ukształtowany w prawie cywilnym reżim odpowiedzialności odszkodowawczej władz publicznych jest właściwym środkiem przeciwdziałania tym niekorzystnym zjawiskom oraz czy można w ogóle mówić w rozpatrywanym przypadku o spełnieniu głównej funkcji odpowiedzialności odszkodowawczej, czyli wyrównaniu poniesionej szkody. 
W ramach tego zjawiska ścierają się interesy różnych grup. Po pierwsze, należy tu wymienić słuszny, zrozumiały interes obywateli, by żyć w zdrowym środowisku naturalnym. Po drugie, występują interesy osób, które dzięki tego typu zjawiskom chcą zaistnieć w przestrzeni publicznej. Po trzecie, występuje interes władz publicznych, które dążą raczej do minimalizowania wydatków publicznych niż do ich zwiększania, gdyż borykają się z permanentnym deficytem finansów publicznych. Po czwarte, interes władz publicznych należy odróżnić od interesu osób pełniących funkcje publiczne, które nie zawsze chcą zdobyć się na wysiłek związany z podjęciem na wielu płaszczyznach intensywnych działań ograniczających zjawisko zanieczyszczania powietrza. Można tu mówić również o mniej lub bardziej doraźnych interesach politycznych, w tym interesach grup, które nie są zainteresowane tym, by przeznaczać większe środki na zmniejszenie zanieczyszczenia powietrza, ponieważ wówczas one dostałyby mniejsze środki publiczne na realizację własnych celów. Należy jeszcze wskazać interesy kancelarii prawnych, które zachęcają do wytaczania procesów, w tym również do wnoszenia pozwów grupowych, przeciwko państwu o odszkodowanie za większe lub mniejsze realne szkody związane z życiem w zanieczyszczonym środowisku naturalnym.

W wyroku Sądu Rejonowego dla Warszawy-Śródmieścia w Warszawie z dnia 24 stycznia 2019 r. (VI C 1043/18) ${ }^{1}$ oraz w wyroku Sądu Rejonowego dla Miasta Stołecznego Warszawy z dnia 1 października 2019 r. (II C 661/19) ${ }^{2}$ zostały zasądzone kilku powodom zadośćuczynienia od Skarbu Państwa na wskazane przez nich cele społeczne ${ }^{3}$. Sądy rejonowe uznały, iż zostało naruszone dobro osobiste powodów w postaci ich prawa do korzystania z walorów nieskażonego środowiska naturalnego, a zwłaszcza do życia w środowisku odpowiadającym co najmniej normom określonym w prawodawstwie Unii Europejskiej. Ponadto zostały jeszcze naruszone takie dobra osobiste, jak: prawo do ochrony życia prywatnego, prawa do wolności, prywatności i poszanowania miejsca zamieszkania oraz zdrowie. Przy czym naruszenie dobra osobistego, jakim jest zdrowie, nastąpiło - w ocenie sądów - nie poprzez uszczerbek na zdrowiu, a tylko poprzez naruszenie bezpieczeństwa zdrowia, rodzące lęk o stan zdrowia. Zdaniem sądów powodowie doznali krzywdy polegającej na znoszeniu cierpień psychicznych związanych z zagrożeniem egzystowania w zanieczyszczonym środowisku. W obszernych uzasadnieniach sądy orzekające odwołały się do koncepcji dotyczących prawa człowieka do życia w nieskażonym środowisku naturalnym, a także do

1 Według informacji ze strony Portal Orzeczeń Sądu Rejonowego dla Miasta Stołecznego Warszawy w Warszawie na dzień 25 czerwca 2020 r. wyrok ten jest nieprawomocny.

2 Według informacji ze strony Portal Orzeczeń Sądu Rejonowego dla Warszawy-Śródmieścia w Warszawie na dzień 25 czerwca 2020 r. wyrok ten jest nieprawomocny.

3 Jak donoszą media, w identycznym duchu wypowiedział się Sąd Rejonowy dla Warszawy-Śródmieścia w wyroku z dnia 17 stycznia 2020 r., zasądzając zadośćuczynienie w wysokości 10000 zł na rzecz powódki solidarnie od Skarbu Państwa i Miasta Stołecznego Warszawy. 
aktów prawa międzynarodowego, a zwłaszcza do prawa Unii Europejskiej oraz europejskiej Konwencji praw człowieka i podstawowych wolności. Jako podstawę prawną rozstrzygnięć sądy wskazały art. 448 ustawy z dnia 23 kwietnia 1964 r. Kodeks cywilny (t.j. Dz.U. 2019, poz. 1145; dalej: k.c.) w związku z art. 23, 24 oraz 417 k.c. Zdaniem sądów nie budzi wątpliwości bezprawność zachowań funkcjonariuszy państwa polskiego. Stwierdziły w szczególności, iż Trybunał Sprawiedliwości Unii Europejskiej (dalej: TSUE) w wyroku z dnia 22 lutego 2018 r. w sprawie C-336/16, wydanym na skutek skargi Komisji Europejskiej wniesionej na podstawie art. 258 Traktatu o funkcjonowaniu Unii Europejskiej (dalej: TfUE), stwierdził naruszenie przez Polskę art. 13 ust. 1 dyrektywy Parlamentu Europejskiego i Rady 2008/50/WE z dnia 21 maja 2008 r. w sprawie jakości powietrza i czystszego powietrza dla Europy (Dz.Urz. UE L 152 z 11.06.2008) z uwagi na przekroczenie dobowych wartości dopuszczalnych dla PM10 w szeregu stref i aglomeracji. W ten sposób TSUE przychylił się do skargi Komisji Europejskiej i uznał za nieprzekonujące argumenty polskiego rządu, który wywodził, że zejście poniżej określonych w dyrektywie progów zanieczyszczenia powietrza jest na znacznym obszarze Polski wielce utrudnione ze względu na szczególne warunki klimatyczne, znaczące źródła zanieczyszczenia powietrza, sytuację społeczno-gospodarczą kraju, jak również jego historyczne i kulturowe uwarunkowania ${ }^{4}$. Wyrok TSUE nie nałożył jakiegokolwiek obowiązku odszkodowawczego na państwo polskie ani nawet jakiejkolwiek kary pieniężnej ${ }^{5}$. Należy jednak zwrócić uwagę, że w świetle orzecznictwa TSUE wyrok wydany na podstawie art. 258 TfUE (dawny art. 226 Traktatu ustanawiającego Wspólnotę Europejską) może stanowić pierwszy krok w procedurze dochodzenia odszkodowania. Będzie tak wtedy, gdy państwo członkowskie nie zaprzestanie naruszeń prawa unijnego pomimo wydania przez TSUE orzeczenia stwierdzającego to naruszenie ${ }^{6}$. Wyrok ten jest prawomocny. Co do zasady, wszystkie organy władzy publicznej państw członkowskich, w tym sądy, mają obowiązek go przestrzegać. Takie przekonanie wywodzi się m.in. z zasady lojalności, zapisanej w art. 4 ust. 3 Traktatu o Unii Europejskiej.

Jak podaje Rzecznik Praw Obywatelskich (dalej: RPO) na swojej stronie internetowej, Sąd Okręgowy w Gliwicach na początku 2020 r. wystąpił do Sądu Najwyższego (dalej: SN) z następującym pytaniem prawnym: „Czy prawo do życia w czystym

4 Zob. E. Radecka, Wyrok Trybunału Sprawiedliwości Unii Europejskiej z dnia 22 lutego 2018 r. w sprawie C336/16 Komisja Europejska vs. Rzeczpospolita Polska - konsekwencje prawne [w:] Prawne instrumenty ochrony powietrza. Wybrane zagadnienia, red. F. Nawrot, E. Radecka, Katowice 2019, s. 97 i n. (publikacja dostępna na stronie http:// www.kpgios.us.edu.pl).

5 Kara taka może być w przyszłości nałożona na podstawie art. 260 ust. 2 TfUE, gdyby pomimo wydania tego wyroku Polska nie zmniejszyła poziomu zanieczyszczenia powietrza zgodnie z dyrektywą. Zob. ibidem, s. 98 i n.

6 Zob. wyrok TSUE z dnia 5 marca 1996 r. w sprawach połączonych C-46/93 i C-48/93 Brasserie du pêcheur i Factorame, EU:C:1996:79, pkt 57. 
środowisku, umożliwiające oddychanie powietrzem atmosferycznym spełniającym standardy jakości określone w przepisach powszechnie obowiązującego prawa w miejscach, w których osoba przebywa przez dłuższy czas, w szczególności miejscu zamieszkania, stanowi dobro osobiste podlegające ochronie na podstawie art. 23 w zw. z art. 24 i art. 448 Kodeksu cywilnego?”. Zdaniem RPO uchwała, którą SN może podjąć w odpowiedzi na powyższe pytanie, będzie niezwykle istotna dla dochodzenia roszczeń cywilnoprawnych z tytułu zanieczyszczenia środowiska.

W moim przekonaniu niebagatelne znaczenie dla niniejszych rozważań ma fakt, iż powodami we wskazanych sprawach, w których orzekały warszawskie sądy rejonowe ${ }^{7}$, były osoby powszechnie znane, wywodzące się z kręgów artystycznych (literackich), względnie związane z szeroko pojętymi mediami elektronicznymi. Osoby takie są współcześnie nazywane „celebrytami” ${ }^{8}$. Niejednokrotnie w swych poczynaniach kierują się one odmienną logiką niż inni członkowie społeczeństwa, w tym konwencją happeningu. Nie chcę być źle zrozumiany. Nie neguję tego, że osobom takim może przyświecać godny pochwały zamiar w tym przypadku chodziło, jak deklarowali, o: zainteresowanie szerokich kręgów społecznych problemem zanieczyszczonego powietrza, wzbudzenie dyskusji o roli państwa (władzy publicznej) w rozwiązywaniu tego problemu i pobudzenie funkcjonariuszy publicznych do działania na tym polu. Osoby te niewątpliwie przynajmniej częściowo swój cel osiągnęły. Wskazane wyroki, mimo iż nie są prawomocne, odbiły się szerokim echem w środkach masowego przekazu. Pojawiły się też zapowiedzi zachęconej tym sukcesem kancelarii prawnej wniesienia pozwów zbiorowych przeciwko Skarbowi Państwa w imieniu kilkuset powodów. We wskazanych przypadkach należy jednak ściśle odróżnić wymiar medialny od jurydycznego. Prawnicy bowiem, a sędziowie przede wszystkim, powinni w swych działaniach i analizach kierować się innego rodzaju logiką. Każdego prawnika, nawet tego, który nie specjalizuje się w tematyce odpowiedzialności odszkodowawczej władz publicznych, tego rodzaju pozwy, a tym bardziej wyroki zasądzające, powinny skłaniać do refleksji. Podkreślmy to, że sądy rejonowe, zasądzając odszkodowanie (zadośćuczynienie), nie żądały nawet wykazania przez powodów wystąpienia konkretnej jednostki chorobowej pozostającej $\mathrm{w}$ adekwatnym związku przyczynowym $\mathrm{z}$ faktem egzystencji $\mathrm{w}$ zanieczyszczonym powietrzu. Uznały za wystarczające wykazanie przez powodów, iż w miejscu, w którym zamieszkują, dochodzi do regularnego przekraczania dopuszczalnych w dyrektywie unijnej poziomów zanieczyszczenia powietrza. Ich szkoda (krzywda) miała polegać głównie na wystąpieniu dyskomfortu psychicznego (stanu zagrożenia). W ten sposób doszło, zdaniem sądów, do naruszenia dobra osobistego

Patrz przypisy $1-3$.

8 Słowo „celebryta” weszło już do języka prawniczego. Zob. T. Grzeszak, Celebryci kontra tabloidy, czyli o nowych funkcjach zadośćuczynienia, „Zeszyty Naukowe Uniwersytetu Jagiellońskiego. Prace z Prawa Własności Intelektualnej” 2007, z. 100, s. 130. 
w rozumieniu art. 23 k.c. Sądy oparły się na ogólnej wiedzy w tym zakresie i nie uznały za konieczne przeprowadzenie dowodu z opinii biegłych.

Pojawia się pytanie, czy zasądzając odszkodowanie (zadośćuczynienie) od państwa i od jednostki samorządu terytorialnego za naruszenie dobra osobistego w postaci prawa każdego z powodów do życia w środowisku odpowiadającym obowiązującym normom, nie wykraczamy daleko poza ramy klasycznego mechanizmu odpowiedzialności odszkodowawczej. Sensowności tego pytania nie osłabia nawet fakt, iż reżim odpowiedzialności odszkodowawczej władz publicznych cechuje się określoną specyfiką.

Niekiedy można odnieść wrażenie, iż informacje o wygranych procesach odszkodowawczych przeciwko państwu z tego tytułu budzą rodzaj zachwytu nad efektywnością współczesnego systemu prawnego. Pojawiają się sugestie, iż reżim odpowiedzialności władz publicznych, a wraz z nim system ochrony praw człowieka, osiągnął współcześnie, przynajmniej w państwach europejskich, szczytowy etap rozwoju, gdyż pozwala dochodzić od państwa wyrównania tego rodzaju wysublimowanych szkód (krzywd), co jeszcze kilkanaście, a nawet kilka lat temu wydawało się niemożliwe lub niewyobrażalne. Można spotkać się też ze stwierdzeniem, iż być może osiągnęliśmy również szczytowy etap rozwoju świadomości prawnej obywateli, którzy wreszcie zdali sobie sprawę, że państwo wobec nich ma szereg realnych zobowiązań. Naturalną konsekwencją takiego założenia jest sformułowanie tezy, iż należy przemyśleć, jakie jeszcze inne niedogodności życia doświadczane przez nas codziennie są wynikiem zaniedbań ze strony państwa lub pozostałych władz publicznych. Gdy już je ustalimy, będziemy mieli prawo dochodzić z tego tytułu od państwa lub innych władz publicznych odszkodowania (zadośćuczynienia).

Tego rodzaju założenia i poglądy siłą rzeczy pojawiają się przy okazji rozpowszechniania informacji o skutecznym sądowym dochodzeniu zadośćuczynienia za naruszenie dobra osobistego polegającego na prawie do korzystania z walorów nieskażonego środowiska naturalnego. Zyskują one silne wsparcie w kręgach opiniotwórczych. Należy odnotować, iż RPO już wcześniej opowiedział się po stronie osób wnoszących takie pozwy ${ }^{9}$.

Rodzi się jednak fundamentalne pytanie, czy takie sugestie i założenia rzeczywiście są trafne. Być może jest na odwrót - tzn. dochodzone roszczenia o zadośćuczynienie od Skarbu Państwa i jednostek samorządu terytorialnego z tego tytułu oraz wydawane wyroki zasądzające są wynikiem nie tyle dojrzałości świadomości prawnej współczesnego człowieka i efektywności systemu prawnego, ile narastania postawy roszczeniowej, a także przejawem dominacji określonych trendów myślowych wykazujących cechy ideologii ${ }^{10}$.

9 Zob. pismo procesowe RPO z 30 listopada 2018 r. do Sądu Okręgowego w Gliwicach, sygn. akt III Ca 1548/18.

10 Zob. np. E. Kwidzyński, Ekologizm jako ideologia polityczna na przykładzie Niemiec i Francji, „Ogrody Nauk i Sztuk” 2015, nr 5, s. 125-132. 


\section{Klasyczny reżim odpowiedzialności odszkodowawczej}

Jak pisał Andrzej Stelmachowski, prawo cywilne w swej klasycznej formie jest przepojone duchem indywidualizmu ${ }^{11}$. Mechanizmy wypracowane w prawie cywilnym sprawdzają się w sytuacjach występowania relacji między jednostkami prywatnymi, a przede wszystkim - w relacjach między osobami fizycznymi. Obszar ten można nazwać, za Franzem Bydlinskim, „jądrem materii cywilnoprawnej" (Kernbereich) ${ }^{12}$. Natomiast przypadki, gdy po jednej stronie stosunku występowało państwo, od wieków budziły problemy w cywilistyce. $Z$ wieloma tymi problemami cywilistyka sobie poradziła. Dotyczy to m.in. samej idei ponoszenia przez państwo odpowiedzialności odszkodowawczej za szkody wyrządzone jednostce przez jego funkcjonariuszy. Nie wszystkie kwestie uczestnictwa państwa w obrocie cywilnoprawnym zostały jednak do końca rozwiązane. W prawie cywilnym, przepojonym duchem indywidualizmu, wielokrotnie bowiem problematyczne stawały się zjawiska cechujące się pewną masowością, a z istnieniem państwa wiążą się właśnie problemy w skali makro - ze względu na rozległość jego funkcjonowania, różnorodne formy aktywności (akty normatywne, akty administracyjne, orzeczenia sądowe, akty przymusu bezpośredniego, instrumenty prawa cywilnego) oraz fakt, iż jest ono uosobieniem całego społeczeństwa. Tych problemów niejednokrotnie nie da się ani zamknąć w obrębie jednostkowego stosunku prawnego, ani rozwiązać dzięki przyjęciu perspektywy takiego jednostkowego stosunku. $Z$ takim właśnie przypadkiem mamy do czynienia przy analizie problematyki ewentualnej odpowiedzialności odszkodowawczej za skutki egzystencji obywateli w zanieczyszczonym środowisku naturalnym.

Klasyczny mechanizm odpowiedzialności odszkodowawczej można przeanalizować, opierając się na kanonach typowego rozumowania prawniczego, jakim jest subsumcja. Organ orzekający ustala zaistnienie kilku przesłanek tej odpowiedzialności, tj. wystąpienie: szkody o określonym rozmiarze, zachowania sprawcy oraz adekwatnego związku przyczynowego między tym zachowaniem a powstałą szkodą. Do powstania odpowiedzialności odszkodowawczej jest jeszcze wymagane ustalenie winy sprawcy ( $\mathrm{w}$ prawie polskim $\mathrm{w}$ odniesieniu do władz publicznych ta przesłanka - przynajmniej teoretycznie - nie jest wymagana, o czym niżej), nazywanej klasyczną zasadą tej odpowiedzialności, aczkolwiek rozumienie winy na przestrzeni dziesiątków lat ewoluuje i coraz bardziej ulega obiektywizacji. W niektórych przypadkach odpowiedzialność odszkodowawcza wystąpi na zasadzie ryzyka, a więc bez konieczności wykazania winy, czy nawet na zasadzie słuszności. Jeżeli mamy do czynienia ze sprawcą (względnie osobą odpowiedzialną za sprawcę) i poszkodowanym będącymi wyłącznie oso-

11 A. Stelmachowski, Wstęp do teorii prawa cywilnego, Warszawa 1984, s. 208.

12 Zob. F. Bydlinski, Kriterien und Sinn der Unterscheidung von Privatrecht und öffentlichem Recht, „Archiv für die civilistische Praxis” 1994, Band 1094, s. 339. 
bami prywatnymi, zwłaszcza osobami fizycznymi, ograniczenie analizy prawnej do ustalania wskazanych przesłanek i zasad odpowiedzialności jest w pełni wystarczające. W sytuacji natomiast, gdy odpowiedzialność za szkodę ma ponieść państwo, ograniczenie analizy prawnej do wskazanych przesłanek i zasad może okazać się zbytnim uproszczeniem zagadnienia. Innymi słowy, można wówczas narazić się na zarzut nieuchwycenia istoty problemu. Powstaje nieodparte wrażenie, że sądy rejonowe, które zasądziły zadośćuczynienie za krzywdę polegającą na naruszeniu dobra osobistego w postaci prawa do korzystania z walorów nieskażonego środowiska naturalnego, taki właśnie błąd popełniły. Ograniczyły się bowiem (niezależnie od rozległości uzasadnienia wyroków, w których nawiązywały do prawa międzynarodowego, w tym prawa UE oraz orzecznictwa Europejskiego Trybunału Praw Człowieka; dalej: ETPC) do analizy klasycznych przesłanek odpowiedzialności odszkodowawczej, czyli do klasycznego, cywilistycznego mechanizmu kompensacyjnego. Tymczasem mechanizmy klasycznej cywilistyki nie były tworzone $\mathrm{z}$ myślą o takich masowych zjawiskach. W konsekwencji nawet jeżeli przyjmiemy istnienie owego dobra osobistego, czyli prawa do życia w czystym powietrzu, co już samo w sobie jest kontrowersyjne ${ }^{13}$, oraz stwierdzimy jego naruszenie w wyniku niewykonania przez państwo polskie postanowień dyrektywy Parlamentu Europejskiego i Rady 2008/50/WE z dnia 21 maja 2008 r., nie można jeszcze mówić o wystarczających podstawach do zasądzenia odszkodowania od Skarbu Państwa czy jednostek samorządu terytorialnego.

Nawiasem mówiąc: ETPC w żadnym z wyroków nie analizował sprawy analogicznej do rozpatrywanej we wskazanych procesach. W szczególności żadna ze spraw rozpatrywanych przez ETPC nie dotyczyła tak masowego zjawiska, jak skala zanieczyszczenia powietrza w Polsce. Zwracając uwagę na obowiązki państwa, ETPC koncentrował się najczęściej na przypadkach, gdy bezpośrednim źródłem zanieczyszczeń była aktywność konkretnych zakładów przemysłowych czy innych przedsiębiorców. Odpowiedzialność państwa miała natomiast wynikać z wydania błędnych decyzji lokalizacyjnych czy też decyzji pozwalających na emisję zanieczyszczeń, względnie z braku odpowiedniego nadzoru ${ }^{14}$.

13 Jak twierdzi Mariusz Gaweł, pomimo że prawo do życia w czystym środowisku naturalnym zalicza się obecnie do zbiorczych praw człowieka trzeciej generacji, prawo to nie jest samoistnym dobrem osobistym. Ochronie podlega tylko w przypadku jego naruszenia w korelacji z innym obiektywnie naruszonym oraz klasyfikowanym dobrem osobistym. Zob. M. Gaweł, Prawo do życia w czystym środowisku a ochrona powietrza w kontekście zagadnienia dóbr osobistych oraz zaniechań legislacyjnych [w:] Prawne instrumenty ochrony powietrza. Wybrane zagadnienia, red. F. Nawrot, E. Radecka, Katowice 2019, s. 16 i n. Podobnie orzekł Sąd Apelacyjny w Katowicach w wyroku z dnia 22 stycznia 2014 r., V ACa 649/13, Lex nr 1439040.

14 Por. np. wyrok ETPC z dnia 2 listopada 2006 r. w sprawie Giacomelli v. Włochy, skarga nr 59909/00. Zob. M. Behnke, Zanieczyszczenie środowiska jako naruszenie prawa do prywatności - refleksje na tle orzecznictwa Europejskiego Trybunału Praw Czło- 


\section{Zasada równości wobec ciężarów publicznych jako najważniejsza zasada odpowiedzialności odszkodowawczej władz publicznych}

Wydaje się, iż do tej pory nie udało się w skali Europy osiągnąć pełnego konsensusu w kwestii fundamentalnej, tzn. najtrwalszej zasady odpowiedzialności odszkodowawczej władz publicznych ${ }^{15}$. Dlatego też w dalszym ciągu balansujemy między trzema możliwościami: a) między wymogiem a brakiem wymogu winy; b) między stratyfikacją odpowiedzialności w oparciu o koncepcję dwoistej natury działań państwa i innych podmiotów publicznych (dychotomia imperium-dominium) a reżimem kontestującym ten podział dla celów odpowiedzialności odszkodowawczej; c) między klasyczną odpowiedzialnością deliktową a różnymi rozwiązaniami z zakresu repartycji, które niekiedy są zaliczane do instytucji prawa publicznego.

Nie rozwiążemy tych dylematów bez odnalezienia głębszej podstawy (zasady) tej odpowiedzialności. Jako inspiracja w tych poszukiwaniach mogą posłużyć rozwiązania francuskie. Francja od końca XIX w. jest w awangardzie ewolucji reżimu odpowiedzialności odszkodowawczej władz publicznych. Dorobek francuskiego orzecznictwa administracyjnego i doktryny w tym zakresie należy już dziś uznać za dziedzictwo europejskiej kultury prawnej. W nauce francuskiej fundamentalną zasadę tej odpowiedzialności od ponad 100 lat najczęściej upatruje się w idei równości obywateli wobec ciężarów publicznych ${ }^{16}$.

Zasada równości wobec ciężarów publicznych wyrosła z założeń idei solidarności społecznej, której jednym z autorów był Léon Duguit. To nie przypadek, że ten francuski teoretyk prawa specjalizował się m.in. w tematyce odpowiedzialności odszkodowawczej władz publicznych. Pisał: „Działalność państwa jest prowadzona w interesie całej społeczności; dlatego też ciężary wiążące się z tą działalnością nie mogą być ponoszone przez poszczególne jednostki w różnym stopniu. [...] Państwo w pewnym sensie odgrywa rolę ubezpieczyciela tzw. ryzyka społecznego wiążącego się z jego funkcjonowaniem. [...] Odpowiedzialność państwa zawsze opiera się na tej idei, nawet gdy nie występuje wina konkretnego funkcjonariusza"17.

Sądzę, że również na gruncie polskim idea równości wobec ciężarów publicznych de lege lata powinna być uznana za taką fundamentalną zasadę tej odpowiedzialności. Silnych argumentów na poparcie tej tezy dostarcza Konstytucja

wieka [w:] Prawa człowieka a ochrona środowiska. Wspólne wartości i wyzwania, red. B. Gronowska, B. Rakoczy, J. Kapelańska-Pręgowska, K. Karpus, P. Sadowski, Toruń 2018, s. 11 i n.

15 Joanna Kuźmicka-Sulikowska nazywa tę zasadę „racją, która uzasadnia nałożenie na dany podmiot obowiązku świadczenia odszkodowawczego”. Zob. J. Kuźmicka-Sulikowska, Zasady odpowiedzialności deliktowej $w$ świetle nowych tendencji $w$ ustawodawstwie polskim, Warszawa 2011, s. 31.

16 Ibidem.

17 L. Duguit, Traité de droit constitutionnel, t. III, La théorie générale de létat, Paris 1923, s. 433-435 (tłum. własne). 
Rzeczypospolitej Polskiej z dnia 2 kwietnia 1997 r. (Dz.U. 1997, nr 78, poz. 483; dalej: Konstytucja). Postępujący proces konstytucjonalizacji prawa cywilnego daje podstawy do poszukiwania w ustawie zasadniczej takiej fundamentalnej zasady. Już w preambule do Konstytucji czytamy bowiem, iż obywatele Rzeczypospolitej Polskiej są „równi w prawach i w powinnościach wobec dobra wspólnego - Polski”. Z kolei art. 2 Konstytucji nakazuje urzeczywistniać w Rzeczypospolitej Polskiej zasady sprawiedliwości społecznej. We wszystkich epokach i koncepcjach filozoficznych idea sprawiedliwości wiązała się i wciąż wiąże z ideą równości. Szczególnie jest to widoczne w naukach prawnych, również gdy podkreśla się, iż sprawiedliwość i równość nie są pojęciami tożsamymi ${ }^{18}$. Jeżeli nawet dobra i ciężary społeczne nie mają być dzielone stricte równo, to jednak musi być zachowana przynajmniej proporcja między przyznanymi dobrami i nakładanymi ciężarami a warunkami społecznymi, w których znalazły się poszczególne jednostki, oraz ich zasługami. Innymi słowy, tylko obiektywne wymogi i kryteria mogą uzasadniać nierówne traktowanie obywateli. Założenie takie pojawia się w orzecznictwie Trybunału Konstytucyjnego (dalej: TK) ${ }^{19}$. Jest ono zwane sprawiedliwością rozdzielczą albo równością proporcjonalną.

Do idei równości wprost odwołuje się polski ustrojodawca w art. 32 Konstytucji. Powszechnie uważa się, że przepis ten konstytuuje zasadę równości jako naczelną zasadę polskiego systemu prawnego ${ }^{20}$.

W polskiej nauce prawa konstytucyjnego można natrafić na poglądy całkowicie współgrające z twierdzeniami formułowanymi przez L. Duguita. Jak pisał Wojciech Sokolewicz, „nakaz urzeczywistniania zasad sprawiedliwości społecznej, adresowany do państwa, jest ściśle związany z ideą sprawiedliwości jako taką, będącą u podstaw całej konstytucji - nakaz ten łączy się z pojmowaniem państwa jako dobra wspólnego (art. 1) oraz obowiązkiem solidarności z innymi"21. W konsekwencji silne podstawy konstytucyjne ma twierdzenie, iż odpowiedzialność odszkodowawcza państwa jest uzasadniona wówczas, gdy zostanie naruszona zasada równości obywateli w ponoszeniu ciężarów publicznych.

Do idei równości nawiązuje także rozpowszechniające się współcześnie w świecie pojęcie sprawiedliwości ekologicznej. Istota sprawiedliwości ekologicznej ma polegać na równym traktowaniu wszystkich ludzi we wszystkich sprawach związanych ze środowiskiem, a zwłaszcza z dostępem do zasobów środowiska (równy podział surowców, zwłaszcza nieodnawialnych) oraz ponoszeniem ciężarów środowiskowych wynikających z rozwoju cywilizacji ${ }^{22}$.

18 Zob. ks. P. Wróbel, Postulat sprawiedliwości społecznej a idea sprawiedliwości, „Studia Socialia Cracoviensia" 2013, nr 1, s. 136 i n.

Zob. np. wyrok TK z dnia 13 maja 2002 r., SK 32/01, OTK-A 2002, nr 3, poz. 31.

20 Zob. ks. P. Wróbel, op. cit., s. 145 i n.

21 W. Sokolewicz [w:] Konstytucja RP, t. IV, red. L. Garlicki, Warszawa 2003, s. 58-59.

22 Zob. D. Trzcińska, Sprawiedliwość ekologiczna w systemie prawa ochrony środowiska. Wartości czy wyzwania dla praw człowieka? [w:] Prawa człowieka a ochrona środo- 
Także zasadę słuszności wyrażoną w art. $417^{2}$ k.c. należy uznać za wyraz i realizację zasady równości wobec ciężarów publicznych. W literaturze i orzecznictwie formułowano pogląd, iż przepis ten powinien znaleźć zastosowanie przede wszystkim wtedy, gdy szkoda nastąpiła w wyniku działań podejmowanych „W interesie ogółu” ${ }^{\prime 2}$. W stwierdzeniu tym można łatwo dostrzec reminiscencje wypracowanej we francuskim orzecznictwie administracyjnym i francuskiej doktrynie zasady solidaryzmu społecznego oraz równości obywateli wobec ciężarów publicznych. Już uzasadnienie sejmowe do art. 5 ustawy z dnia 15 listopada 1956 r. o odpowiedzialności państwa za szkody wyrządzone przez funkcjonariuszy państwowych (Dz.U. nr 54, poz. 243) - przepisu będącego poprzednikiem art. 419 k.c., którego z kolei odpowiednikiem jest obecny art. $417^{2}$ k.c. - nie pozostawiało żadnych wątpliwości, że u podstaw wprowadzenia tego przepisu legły idee równości wobec ciężarów publicznych oraz solidaryzmu społecznego ${ }^{24}$. Odpowiedzialność na zasadzie słuszności daje możliwość przyznania jednostce odszkodowania od władzy publicznej w przypadku naruszenia zasady równości wobec ciężarów publicznych, gdy sytuacja ma charakter nietypowy, tzn. nie wystąpiły pozostałe przesłanki odpowiedzialności, a zwłaszcza bezprawność.

\section{Modyfikacja przesłanek odpowiedzialności odszkodowawczej oraz dorozumiane (ukryte) przesłanki odpowiedzialności odszkodowawczej władz publicznych}

Dalsze wywody prowadzą do wniosku, iż zasada równości wobec ciężarów publicznych jako podstawa odpowiedzialności władz publicznych znajduje uzasadnienie nie tylko w Konstytucji, ale także w elementarnych regułach prakseologii oraz zdrowego rozsądku.

Już wiele lat temu zwrócono uwagę, zwłaszcza w nauce francuskiej, że owa głębsza podstawa odpowiedzialności władz publicznych wpływa na przyjęcie rozwiązań bardziej szczegółowych i technicznych ${ }^{25}$. W literaturze francuskiej podkreśla się np., iż wina i ryzyko nie są podstawami (zasadami) odpowiedzialności deliktowej władz publicznych. Stanowią one w rzeczywistości tylko przesłanki (la condition) pociągnięcia administracji do odpowiedzialności.

wiska. Wspólne wartości i wyzwania, red. B. Gronowska, B. Rakoczy, J. Kapelańska-

-Pręgowska, K. Karpus, P. Sadowski, Toruń 2018, s. 339.

23 Poglądy i orzecznictwo z poprzedniego systemu prawnego zob.: R. Szczepaniak, Odpowiedzialność odszkodowawcza jednostek samorzadu terytorialnego, Warszawa 2001, s. 123-124 oraz podana tam literatura i orzecznictwo.

24 Zob. J. Kosik, Zasady odpowiedzialności państwa za szkody wyrządzone przez funkcjonariuszów, Wrocław 1961, s. 52 i 210.

25 Zob. A. de Laubadère, J.C. Venezia, J.C. Gaudemet, Traité de droit administratif, t. I, Paris 1994, s. 874. 
Z poglądem tym należy się zgodzić. W szczególności potrzeba urzeczywistnienia sprawiedliwości społecznej, w tym zasady równości wobec ciężarów publicznych, wymusza niejednokrotnie odpowiednią modyfikację przesłanek odpowiedzialności odszkodowawczej. Pojawiają się również przesłanki dorozumiane, czyli niewysłowione wyraźnie w przepisach, aczkolwiek nie mniej ważne. Dobrą ilustracją tej tezy może stać się rozpatrywany przypadek odpowiedzialności państwa za naruszenie prawa do życia w czystym środowisku naturalnym. W opisanych na początku niniejszego artykułu procesach sądy pierwszej instancji przyznały powodom zadośćuczynienie w kwotach od 5000 do 20000 zł. Zastanówmy się, czy wyroki te są do pogodzenia z zasadą równości wobec ciężarów publicznych. Problemem zanieczyszczonego powietrza są dotknięci prawie wszyscy mieszkańcy Polski. Niemal każda stacja pomiarowa odnotowuje zanieczyszczenie powietrza przekraczające unijne normy ${ }^{26}$. Problem dotyczy nie tylko wielkich aglomeracji miejskich, gdzie źródłem zanieczyszczenia jest m.in. intensywny ruch samochodowy, ale także mniejszych miast i miasteczek, gdzie głównym źródłem zanieczyszczenia są domowe instalacje grzewcze spalające węgiel i inne paliwa stałe. Oczywiście poziom zanieczyszczenia jest w poszczególnych miejscowościach i regionach zróżnicowany i zależny od pory roku, niemniej można przyjąć, iż miliony Polaków oddychają powietrzem, którego poziom zanieczyszczenia nie da się pogodzić z przepisami unijnej dyrektywy. Chodzi m.in. o przynajmniej kilkadziesiąt miast powiatowych i kilka wojewódzkich, w których średnioroczny poziom zanieczyszczenia powietrza należy do najwyższych w UE. Jak wiadomo, sama aglomeracja warszawska liczy minimum 2 mln mieszkańców. Przyjmijmy, iż $10 \mathrm{mln}$ obywateli Polski zachęconych wskazanymi wyrokami wniesie podobne powództwa do sądów przeciwko państwu. Liczba ta nie jest przesadzona. Przecież przekroczone normy zanieczyszczenia powietrza występują dość regularnie na przeważającej części terytorium Polski. Załóżmy, że każdemu z powodów sądy zasądziłyby tylko 5000 zł zadośćuczynienia. Suma zasądzonych kwot przeciwko państwu, przy uwzględnieniu nie tylko kwoty głównej, ale też odsetek oraz kosztów postępowania, w tym kosztów zastępstwa procesowego, wynosiłaby ponad 60 mld zł. Do tego należałoby dodać kolejne wielkie, choć trudniej wycenialne koszty wymiaru sprawiedliwości ponoszone w związku z obsłużeniem tak dużej liczby procesów oraz ogromne koszty obsługi prawnej państwa i innych władz publicznych w tych procesach. Dla porównania wskażę, że kwota, którą państwo polskie w 2019 r. w swym budżecie przeznaczyło na naukę i szkolnictwo wyższe, wynosiła ok. 27 mld zł, z kolei kwota przewidziana w tym samym budżecie na całą służbę zdrowia to 95 mld zł. Koszty ogółem poniesione przez państwo z tytułu przegranych procesów sądowych prawdopodobnie byłyby porównywalne do tej ostatniej kwoty.

${ }^{26}$ Zob. P. Łyczko, Jakość powietrza w Polsce na tle UE, https://powietrze.malopolska.pl/ baza/jakosc-powietrza-w-polsce-na-tle-unii-europejskiej [dostęp 13 września 2017 r.]. 
Może pojawić się w tym momencie zarzut, iż autor niniejszego tekstu odwołuje się do argumentu mało jurydycznego. Tak jednak nie jest. Zarzut taki mogłaby postawić jedynie osoba, która odwołuje się do opisanego wyżej wąsko pojętego, klasycznego mechanizmu odszkodowawczego. W rzeczywistości mamy do czynienia z argumentem na wskroś jurydycznym. To prawda, że w przeszłości, począwszy od XIX w., gdy zaczęto poważnie zastanawiać się nad zagadnieniem odpowiedzialności odszkodowawczej państwa wobec obywateli, wielokrotnie był podnoszony argument, iż taka odpowiedzialność spowoduje załamanie finansów publicznych. Pomimo stałego poszerzania zakresu tej odpowiedzialności do niczego takiego jednak na przestrzeni ponad 100 lat nie doszło, a wskazane argumenty niejednokrotnie zostały podważone, a nawet skompromitowane. Mimo to gdzieś jest granica, po której przekroczeniu wypowiadane w przeszłości obawy mogłyby się ziścić. Już chociażby przedstawione powyżej zestawienie wskazuje, iż przyjęcie przez kolejne sądy podobnej postawy orzeczniczej byłoby prostą drogą do pozbawienia państwa polskiego zdolności do wykonywania jego podstawowych zadań. Należy ponadto wziąć pod uwagę, iż mogłoby też dojść do zalewu sądów pozwami, co w konsekwencji wydłużyłoby rozpatrywanie wszystkich innych spraw. Mielibyśmy więc do czynienia ze skrajnym przypadkiem lekceważenia dobra wspólnego wszystkich obywateli, czyli - Polski, a zarazem pogwałcenia zasady solidarności społecznej.

Warto odnotować, że w ostatnich latach w orzecznictwie zarówno SN, jak i TK jest zauważalny wyraźny trend nakierowany na ochronę równowagi budżetowej TK i SN zaczynają nadawać tej równowadze rangę wręcz zasady konstytucyjnej, pomimo wyrażania w literaturze krytycznych opinii na ten temat. W szczególności kwestionuje się istnienie wyraźnej podstawy konstytucyjnej takiego zabiegu ${ }^{27}$. Można zaryzykować jednak tezę, iż owa równowaga budżetowa urasta do rangi dorozumianej przesłanki odpowiedzialności odszkodowawczej państwa. Przy podejmowaniu rozstrzygnięć SN oraz TK niejednokrotnie uwzględniają takie nakazy rangi konstytucyjnej jak konieczność zachowania równowagi finansów publicznych (art. 216 i art. 220 ust. 1 Konstytucji). Zdaniem SN owa równowaga finansów publicznych „W obecnym stanie konstytucyjnym stała się zwerbalizowaną wartością konstytucyjną"28. Istotnym rozwinięciem tego nurtu myślowego jest wyrok TK z dnia 4 listopada 2015 r. w sprawie OFE (K 1/14, OTK-A 2015, nr 10, poz. 163). W jego świetle troska o równowagę budżetową urasta bowiem do rangi priorytetowej wartości konstytucyjnej i zyskuje tym samym najwyższy wymiar jurydyczny.

27 A. Gorgol, Równowaga budżetowa w świetle orzecznictwa Trybunału Konstytucyjnego, „Państwo i Prawo” 2014, z. 9, s. 28 i n.; R. Szczepaniak, Zmiany w drugim filarze emerytalnym z perspektywy cywilistycznej, „Kwartalnik Prawa Prywatnego” 2016, z. 4, s. 922.

28 Wyrok SN z dnia 4 czerwca 2008 r., II UK 12/08, OSN 2009/21-22, poz. 291. Zob.: wyrok TK z dnia 8 maja 2000 r., SK 22/99, OTK 2000, nr 4, poz. 107; R. Szczepaniak, Zmiany $w$ drugim filarze, op. cit., s. 912-913. 
Nie można zapominać, że - co podkreślał L. Dugiut - państwo jest uosobieniem całego społeczeństwa, a w rozpatrywanym przypadku niemal wszyscy obywatele są w podobnym położeniu. Dlatego z czysto pragmatycznego punktu widzenia nie ma sensu dochodzenie odszkodowania od państwa przez całe społeczeństwo lub znaczną jego część. Oznaczałoby to bowiem, że społeczeństwo wystąpi przeciwko sobie o odszkodowanie. W ten sposób doszłoby jedynie do niepotrzebnej, pracochłonnej i szkodliwej dystrybucji środków. Zabieg taki niweczyłby sens mechanizmu odszkodowawczego w świetle założeń ekonomicznej analizy prawa ${ }^{29}$.

Oczywiście może pojawić się zarzut, iż jest mało prawdopodobne, że wnoszenie pozwów przeciwko państwu o zadośćuczynienia za naruszenie prawa do życia w czystym środowisku naturalnym stanie się tak masowym zjawiskiem. Nie byłby to jednak argument ani przesądzający, ani dotykający istoty problemu. Nie wiemy przecież, jaką skalę to zjawisko osiągnie. Osoby wnoszące pozwy poświęciły wiele energii, by te procesy nagłośnić i zachęcić tym samym inne jednostki do zgłaszania takich roszczeń. Jak zostało wskazane, są już przygotowywane pozwy zbiorowe. Najważniejszy jest jednak inny aspekt sprawy. Załóżmy, że relatywnie niewielka grupa osób takie pozwy wniesie. Co będzie skutkiem wystąpienia o zadośćuczynienie jedynie przez niektórych członków społeczeństwa i wydanie na ich rzecz korzystnego wyroku? Będzie nim naruszenie zasady równości wobec ciężarów publicznych. W wyniku tego bowiem niektórzy obywatele - wbrew konstytucyjnej zasadzie równości - otrzymają zadośćuczynienie, a inni go nie dostaną, pomimo że generalnie wszyscy znajdują się w podobnym położeniu. Wystąpi swoisty paradoks polegający na tym, iż odpowiedzialność odszkodowawcza państwa nie będzie służyć przywróceniu równości w ponoszeniu przez obywateli ciężarów publicznych, lecz wprost przeciwnie - doprowadzi do naruszenia tej równości. Paradoks ten można wyrazić jeszcze dosadniej: osoby, które patrzą dalekowzrocznie i bardziej dbają o dobro wspólne, takiego zadośćuczynienia nie dostaną, bo nie będą się go domagać.

Analiza polskiego systemu prawnego oraz systemu prawnego innych państw UE prowadzi do wniosku, iż owa fundamentalna zasada odpowiedzialności odszkodowawczej państwa jest przestrzegana nawet wtedy, gdy odbywa się to w sposób dorozumiany. W szczególności dowodów dostarcza tu rozumienie przesłanek tej odpowiedzialności: chodzi zwłaszcza o wymóg bezprawności, winy, a w mniejszym stopniu - związku przyczynowego i szkody.

29 Prawnicy amerykańscy w analizach odwołują się do poglądów ekonomistów na temat optymalnych pod względem potrzeb społecznych zasad dystrybucji dóbr, których zasób jest ograniczony, oraz rozkładu ryzyka. Zob. ogólnie R.A. Posner, Economic analysis of law, Boston-Toronto 1972. Zob. także J.L. Coleman, The Economic Structure of Tort Law, „The Yale Law Journal” 1988, vol. 97, s. 1233 i n. oraz podana tam bogata literatura przedmiotu. 
Nawet gdy odpowiedzialność odszkodowawcza państwa ma być oderwana od przesłanki winy (tak: prawo polskie, orzecznictwo UE), sposób rozumienia bezprawności jako przesłanki odpowiedzialności odszkodowawczej państwa sprawia, iż wymóg winy ciągle pozostaje swego rodzaju dorozumianą przesłanką, co w konsekwencji zawęża zakres tej odpowiedzialności. Adam Szpunar opowiadał się za „pluralistycznym ujęciem bezprawności”. Jak tłumaczył bowiem, „istnieje tyle bezprawności, ile jest dziedzin prawa" ${ }^{30}$. Na gruncie reżimu odpowiedzialności deliktowej władzy publicznej rozumienie bezprawności ulega jednak dalszym modyfikacjom. Specyfika przesłanki bezprawności w obrębie tego reżimu ma wynikać z charakterystycznej natury prawnej aktywności, jaką jest „wykonywanie władzy publicznej”. Bezprawność na użytek reżimu odpowiedzialności deliktowej władz publicznych staje się więc autonomiczną kategorią prawną. Autor ten wywodzi, iż „wina jest kwalifikowanym rodzajem bezprawności działania czy zaniechania" ${ }^{31}$. W szczególności wina do pewnego stopnia jest ukryta w wymogu „wystarczająco kwalifikowanej bezprawności”, podkreślanym w orzecznictwie TSUE (dawny ETS) odnoszącym się do odpowiedzialności państwa za szkody wyrządzone w wyniku nieimplementowania dyrektyw unijnych ${ }^{32}$.

Kolejnym przejawem szczególnego rozumienia przesłanki bezprawności na użytek odpowiedzialności odszkodowawczej państwa jest wymóg wystąpienia tzw. bezprawności względnej. Już w orzeczeniu w sprawie Frankovich TSUE podkreślił, że tylko naruszenie przepisu prawa wspólnotowego, który przyznaje

30 A. Szpunar, Odpowiedzialność Skarbu Państwa za funkcjonariuszy, Warszawa 1985, s. 132.

31 A. Szpunar, Odpowiedzialność osób zobowiązanych do nadzoru, Warszawa 1978, s. 80.

32 „Manifest illegality”, „sufficiently serious”, „suffisamment caractérisée”, „hinreichend qualifiziert". Zob.: wyrok ETS z dnia 19 listopada 1991 r. w sprawach połączonych C-6/90 i C-9/90 Andrea Frankovich i Danila Bonifaci v. Włochy, ECR 1991, s. I-5357; wyrok ETS z dnia 5 marca 1996 r. w sprawach połączonych C-46/93 i C-48/93 Brasserie du Pêcheur i Factorame v. Niemcy, ECR 1996, s. I-1029. Zob. na ten temat: Z. Banaszczyk, Odpowiedzialność za szkody wyrządzone przy wykonywaniu władzy publicznej, Warszawa 2015, s. 400 i n.; J.J. Skoczylas, Odpowiedzialność państwa za zaniechanie legislacyjne [w:] Czyny niedozwolone $w$ prawie polskim i prawie porównawczym, Materiały Ogólnopolskiego Zjazdu Cywilistów w Toruniu w 2011 r., red. M. Nesterowicz, Warszawa 2012, s. 500. W doktrynie innych państw unijnych można znaleźć opinie, że konieczność wystąpienia bezprawności wystarczająco kwalifikowanej, a nie jedynie tzw. zwykłego naruszenia przepisu, jest swoistym surogatem winy. Jak pisze John Bell, ,if the liability under EU law for failure to implement EU legislation correctly depends on manifest illegality, then we are in the realms of a higher level of fault". J. Bell, Governmental Liability: Some Comparative Reflections, „InDret. Revista para el analisis del derecho" 2006, no. 322, s. 11. Zob. również: R. Rebhahn, Staatshaftung nach dem Recht der Europäischen Gemeinschaft, „Juristische Blätter” 1996, Nr. 12, s. 752; T. von Danwitz, Die gemeinschaftsrechtliche Staatshaftung der Mitgliedstaaten, „Deutsches Verwaltungsblatt” 1997, Nr. 1, s. 6. 
osobie poszkodowanej określone uprawnienia, może rodzić odpowiedzialność odszkodowawczą. Innymi słowy, odszkodowania na skutek naruszenia przepisu wspólnotowego może domagać się tylko taka osoba, która należała do kręgu podmiotów, dla których ochrony został ustanowiony ten przepis ${ }^{33}$. Takie ujęcie bezprawności w literaturze jest najczęściej określane jako „bezprawność względna" ${ }^{34}$. Koncepcja bezprawności względnej jest stosowana nie tylko wobec odpowiedzialności władz publicznych, jednak to w ich przypadku nabiera szczególnego znaczenia. Wymóg ten, bezsprzecznie zawężający odpowiedzialność odszkodowawczą władz publicznych, występuje pod różnymi nazwami i postaciami w większości europejskich krajowych porządków ${ }^{35}$. Pod ich wpływem przeniknął także do orzecznictwa TSUE ${ }^{36}$. Nietrudno zauważyć, iż również w takim ujęciu przesłanki bezprawności kryje się pewien pierwiastek ocenny, a więc subiektywny. W szczególności od oceny danego przypadku przez sąd będzie zależeć uznanie wystąpienia tego wymogu. Wymóg ten był podkreślany w przeszłości zwłaszcza wówczas, gdy przyjęcie odpowiedzialności państwa czy innej władzy publicznej groziło załamaniem finansów publicznych i zalewem pozwów (tzw. floodgate argument ${ }^{37}$ ).

Problematyka bezprawności względnej wiąże się z zagadnieniem poruszanym na całym świecie, a mianowicie kwestią dotyczącą tego, w jakim stopniu zaniechania wykonania obowiązków władzy publicznej o charakterze ogólnym, tj. wobec całego społeczeństwa, mogą być podstawą dochodzenia przezjednostkę roszczenia

\section{wowych (Niemcy, Holandia, Portugalia), w innych zasadę tę wypracowano w orzecz-} nictwie i doktrynie (Austria, Szwajcaria, kraje common law). Zob. ibidem. Przykładem jest $\$ 839$ Bürgerliches Gesetzbuch w związku z art. 34 Grundgesetz für die Bundesrepublik Deutschland, zawierający formułę, iż urzędnik narusza obowiązek urzędowy, który ciąży na nim względem osoby trzeciej („die ihm einem Dritten gegenüber obligende Amtspflicht”). W Niemczech koncepcja ta występuje pod nazwą Normzwecktheorie albo tzw. konstrukcji Drittbezogenheit. Jak pisze Robert Rebhahn, wymóg celu ochrony stanowi niezbędną składową każdej odpowiedzialności opartej na bezprawnym działaniu. Zachowanie jest zakazane lub nakazane, aby osiągnąć określony cel. Jeżeli odpowiedzialność musi już być poniesiona, to należy ponosić ją tylko za naruszenie tych interesów, które chce chronić naruszona norma. Dlatego należy ustalić cel ochrony naruszonej normy. Zauważa się, iż wymóg celu normy ogranicza odpowiedzialność deliktową. Zob. R. Rebhahn, op. cit., s. 755 i n. W Polsce zagadnienie to było analizowane na długo przed wejściem do UE. Zob. m.in.: A. Szpunar, Odpowiedzialność Skarbu Państwa, op. cit., s. 136-137; ibidem.

36

Został wyrażony już w wyroku ETS w sprawie Frankovich. Zob. Z. Banaszczyk, op. cit., s. 236.

37 Zob. P. Stec, Umowy w administracji. Studium cywilnoprawne, Warszawa 2013, s. 141 i podana tam literatura. 
o naprawienie szkody ${ }^{38}$. Wielu prawników w przeszłości argumentowało, iż dany obowiązek państwa został ustanowiony w ogólnym interesie publicznym. W konsekwencji poszczególne jednostki w przypadku niedopełnienia tego obowiązku nie mogą wywodzić roszczeń odszkodowawczych dla siebie. Mamy bowiem do czynienia z pewnym zjawiskiem o charakterze masowym, z obowiązkami wobec całego społeczeństwa ujętego en bloc. Z powodu owej masowości wielokrotnie brak wówczas tzw. specjalnego charakteru szkody - jak mówią Francuzi - aby można dochodzić wynagrodzenia ${ }^{39}$. Jeżeli uszczerbek ponoszą w równej mierze wszyscy obywatele lub znaczna grupa społeczeństwa, wówczas nie można mówić o szkodzie, lecz o ciężarze publicznym, jaki są oni zobowiązani znosić ${ }^{40}$.

Oczywiście reżim odpowiedzialności odszkodowawczej władz publicznych ewoluuje. W przeszłości jako klasyczny przykład takiej aktywności państwa w ogólnym interesie publicznym wskazywano wydawanie aktów normatywnych. A. Szpunar argumentował, że państwo czy inna władza publiczna nie mogą ponosić odpowiedzialności za szkody wyrządzone wydaniem lub zaniechaniem wydania aktu normatywnego ${ }^{41}$.

Ten wybitny polski cywilista $\mathrm{z}$ tych samych przyczyn twierdził ponadto, że roszczenie odszkodowawcze nie będzie uzasadnione, jeżeli funkcjonariusz naruszył normy prawne mające na celu ochronę dobra powszechnego, interesów całej społeczności. Na poparcie swych słów podawał przykład szkody wyrządzonej przez niebezpiecznego przestępcę, który nie został ujęty bądź wskutek niedbalstwa strażnika zbiegł z więzienia. Autor argumentował, iż w razie przyjęcia prawa do odszkodowania od państwa w takich sytuacjach „utonęlibyśmy dosłownie w morzu wszelkiego rodzaju roszczeń odszkodowawczych osób, których interesy zostały naruszone niejako rykoszetem wskutek działania sprawcy" ${ }^{42}$.

Zaprezentowane poglądy A. Szpunara nieco straciły już na aktualności ${ }^{43}$. Niemniej jednak samo przyjęcie, że mamy do czynienia z dobrem osobistym polegającym na prawie do korzystania $z$ walorów nieskażonego środowiska naturalnego, oraz ustalenie, że doszło do jego naruszenia w wyniku przekroczenia norm unijnych, nie przesądzają jeszcze powstania zasadnego roszczenia odszkodowawczego od państwa czy innej władzy publicznej. Należy odpowiedzieć na fundamentalne pytanie, czy zasądzenie odszkodowania nie kłóciłoby się z zasadą równości wobec ciężarów publicznych. Udzielając odpowiedzi na tak postawione pytanie, trzeba wyjaśnić kwestie cząstkowe. Po pierwsze, należy ustalić, jakie-

38 Zob. E. Bagińska, Odpowiedzialność odszkodowawcza za wykonywanie władzy publicznej, Warszawa 2006, s. 215.

39 Zob. A. de Laubadère, J.C. Venezia, Y. Gaudemet, op. cit., s. 905.

40 Zob. na ten temat R. Szczepaniak, Odpowiedzialność odszkodowawcza jednostek, op. cit., s. 261.

41 A. Szpunar, Odpowiedzialność Skarbu Państwa, op. cit., s. 101.

42 Zob. ibidem, s. 138.

43 Zob. przykład zawarty w przypisie 47. 
go typu obowiązki zostały nałożone w drodze dyrektywy na państwo, tzn. czy obowiązek ten nie został ustanowiony jedynie w ogólnym interesie publicznym. Po drugie, trzeba też zwrócić uwagę na fakt, iż ustalenie bezprawności wymaga dokonania interpretacji przepisów prawa. W literaturze prawniczej już dawno zauważono, iż z teoretycznego punktu widzenia są możliwe trzy interpretacje przepisów regulujących zadania władzy publicznej: od maksymalnie szerokiej, prowadzącej do przyjęcia zobowiązania osiągnięcia określonego rezultatu, poprzez umiarkowaną, której skutkiem jest uznanie istnienia obowiązku podjęcia działań leżących w możliwości organów władzy publicznej, do maksymalnie wąskiej, na podstawie której przyjmuje się jedynie uprawnienie, a nie obowiązek działania $^{44}$. Trzecia interpretacja jawi się już a priori jako najmniej zasadna. Najbardziej racjonalna jest interpretacja druga. Jest ona swoistym złotym środkiem. Przyjęcie pierwszej interpretacji byłoby wyrazem niedojrzałej postawy roszczeniowej, nieuwzględniającej realnych możliwości ekonomicznych państwa. Byłaby ona sprzeczna $z$ konstytucyjnym wymogiem traktowania państwa jako dobra wspólnego obywateli. Należy w związku z tym przypomnieć, iż jedną z głównych przyczyn zanieczyszczania powietrza w Polsce jest spalanie w domowych instalacjach grzewczych węgla i innych paliw stałych. Doprowadzenie do istotnej zmiany tego stanu wymagałoby przeprowadzenia złożonego procesu, w którym znaczenie mają czynniki makroekonomiczne. Nie można ich zneutralizować jedynie w drodze administracyjnoprawnych nakazów i zakazów. Chodzi tu - z jednej strony - o relatywnie niską zamożność licznych grup społecznych, a z drugiej o brak możliwości natychmiastowego przeprowadzenia dekarbonizacji gospodarki. Proces owej dekarbonizacji bezsprzecznie musi następować, ale $\mathrm{z}$ wielu powodów powinien się odbywać wskutek ewolucji.

Jak słusznie zauważył Zbigniew Banaszczyk, sądy muszą „postawić tamę przeciwko takim sytuacjom, w których samo ustalenie niezgodności konkretnego aktu normatywnego z Konstytucją dawałoby nieograniczonej liczbie osób podstawę do konstruowania roszczenia względem władzy publicznej”45. Autor niniejszego tekstu idzie jednak jeszcze dalej. W świetle powyższych wywodów nie tylko stwierdzenie naruszenia prawa unijnego, ale nawet dodatkowo uznanie, że zostało w wyniku tego naruszone dobro osobiste, nie przesądzają powstania zasadnego roszczenia odszkodowawczego przeciwko władzy publicznej. Należy bowiem wziąć pod uwagę, czy wystąpiła odpowiednio rozumiana przesłanka bezprawności, a przede wszystkim - czy w wyniku zasądzenia odszkodowania nie doszłoby do naruszenia zasady równości wobec ciężarów publicznych. Oko-

44 Zob. B. Gawlik, A. Kubas, Odpowiedzialność cywilna Skarbu Państwa - Prezydium Rady Narodowej za szkody wynikłe z braku należytej troski o zapewnienie bezpieczeństwa na terenie objętym działalnością Rady Narodowej, „Studia Cywilistyczne” 1971, t. XVII, s. 166.

45 Z. Banaszczyk, op. cit., s. 219. 
liczności te powinien mieć na uwadze SN, który będzie formułował odpowiedź na wskazane wyżej pytanie prawne Sądu Okręgowego w Gliwicach ${ }^{46}$.

Reasumując: odpowiedzialność odszkodowawczą za zanieczyszczone powietrze państwo czy inne władze publiczne mogłyby ponieść tylko wtedy, gdyby wykazano nieproporcjonalnie duży uszczerbek na zdrowiu i adekwatny związek przyczynowy między niewłaściwym zachowaniem państwa czy innej władzy publicznej a tym uszczerbkiem. Musiałyby wystąpić ponadto pozostałe przesłanki tej odpowiedzialności, a zwłaszcza odpowiedni rodzaj bezprawności. W przypadku jej braku zasądzenie odszkodowania byłoby wyjątkowo możliwe, gdyby za jego przyznaniem przemawiały w danej sprawie względy słuszności (art. $417^{2}$ k.c.). Również w tym przypadku warunkiem przyznania odszkodowania powinien być odpowiednio duży uszczerbek na zdrowiu. Tylko wówczas przyznanie odszkodowania (zadośćuczynienia) nie kłóciłoby się z zasadą równości wobec ciężarów publicznych.

\section{Przeobrażenia reżimu odpowiedzialności odszkodowawczej władz publicznych}

Rozwój odpowiedzialności władz publicznych w ostatnich dziesięcioleciach sprawił, że szereg podanych wyżej argumentów (np. te, które podnosił A. Szpunar) przestało być aktualnych. Niemały wpływ na tę ewolucję wywarło orzecznictwo ETPC ${ }^{47}$ oraz TSUE. W szczególności pod wpływem orzecznictwa ETS

46 Zob. wprowadzenie do niniejszego artykułu.

47 Np. na skutek orzecznictwa ETPC w Wielkiej Brytanii zerwano z immunitetem państwa i innych władz publicznych za szkody wyrządzone w wyniku niedopełnienia obowiązków w zakresie tzw. policji administracyjnej. Chodziło m.in. o przypadki, gdy na skutek zaniedbań władz publicznych nie ujęto niebezpiecznego przestępcy, który następnie wyrządził szkodę obywatelowi danej miejscowości, lub gdy funkcjonariusze gminni dopuścili się zaniedbań i pomimo otrzymywanych sygnałów nie udaremnili krzywd wyrządzanych dzieciom przez ich zwyrodniałych rodziców. Zob. wyrok ETPC z dnia 10 maja 2001 r. w sprawie 29392/95, 2001-V Z i in. v. Wielka Brytania. Sądy brytyjskie zasądzają już pod określonymi warunkami odszkodowania w tego rodzaju sprawach. Jak podkreślają jednak, musi zaistnieć odpowiednio bliska relacja pomiędzy poszkodowanym i władzą publiczną („proximity, a relationship of neighbourhood" - określenie to trudno przetłumaczyć na język polski). Chodzi tu o przesłankę z zakresu szeroko pojętej przyczynowości. Podkreśla się bowiem, że wypełnianie zadań policji administracyjnej służy w pierwszej kolejności interesowi ogółu społeczeństwa, ma więc charakter generalny. W konsekwencji tylko wówczas może powstać roszczenie odszkodowawcze między jednostką i władzą publiczną, gdy jest wysoce prawdopodobne, iż zaniechanie pewnych działań wyrządzi szkodę konkretnej jednostce czy konkretnej grupie jednostek. Innymi słowy, musi być lub powinno być oczywiste dla funkcjonariuszy publicznych, że dana jednostka jest w grupie osób, 
(TSUE) nie jest dziś kwestionowana, co do zasady, odpowiedzialność państwa za szkody wyrządzone aktami normatywnymi, w tym ustawami, oraz za zaniechanie ustawodawcze. Nie znaczy to oczywiście, że uzyskanie takiego odszkodowania dotychczas było łatwe. Musi być spełnionych wiele wymogów, w tym musi wystąpić kwalifikowana postać bezprawności, a także musi zostać wyselekcjonowana stosunkowo nieduża grupa jednostek, które doznały szkody. Nie stracił bowiem na znaczeniu wymóg bezprawności względnej. Rozpatrywany przypadek odpowiedzialności za egzystowanie w zanieczyszczonym powietrzu pozornie niewiele się różni od sprawy Frankovich, w której zapadł słynny wyrok ETS. W jednym i drugim przypadku mamy do czynienia z niespełnieniem przez państwo wymogów dyrektywy unijnej. Różnica jest jednak kolosalna. W sprawie Frankovich chodziło o stosunkowo mało złożony przypadek, gdy państwo włoskie nie zrealizowało na czas zadania nałożonego w dyrektywie, polegającego na stworzeniu specjalnego funduszu gwarantującego, iż pracownicy niewypłacalnego przedsiębiorcy otrzymają swoje wynagrodzenie. Skala działań państwa polskiego koniecznych do tego, by zapewnić poziom czystości powietrza określony w dyrektywie, jest natomiast nieporównanie większa, a same te działania są nieporównanie bardziej kosztowne i różnorodne. Jak podkreślał TSUE (dawny ETS), w procesie ustalenia bezprawności należy brać pod uwagę m.in. złożoność stanów faktycznych, które mają być regulowane krajowym aktem normatywnym, oraz złożoność materii prawnej ${ }^{48}$.

Reżim odpowiedzialności odszkodowawczej władz publicznych już od początku XX w. podlegał procesom i tendencjom, które coraz bardziej oddalały go od założeń klasycznej cywilistyki. Seweryn Rosmarin niemal 100 lat temu pisał o próbie wtłoczenia na siłę w ramy cywilistycznych deliktów pewnych zdarzeń, które w rzeczywistości deliktami nie są, po to, aby za pomocą tego zabiegu można było obciążyć państwo odpowiedzialnością odszkodowawczą. Pisał więc obrazowo, powołując się na poglądy Ottona Mayera, jednego z luminarzy niemieckiej nauki prawa administracyjnego, o „torturowaniu przepisów kodeksu cywilnego” oraz „łamańcach dla zachowywania pozorów, jakoby stosowano prawo odszkodowania za delikty" ${ }^{49}$.

których dotyczy większe ryzyko, a więc szczególnie narażonych na powstanie szkody w wyniku zaniechania podjęcia działań. Ponadto za przyznaniem odszkodowania w konkretnej sprawie muszą przemawiać takie wartości (argumenty), jak: słuszność, sprawiedliwość i zdrowy rozsądek. Zob. S. Tofaris, S. Steel, Police liability in negligence for failure to prevent crime: time to rethink, „University of Cambridge, Faculty of Law Legal Studies Research Paper Series” 2014, no. 39, s. 23.

Zob. wyrok w połączonych sprawach C-46/93 i C-48/93 Brasserie du Pêcheur i Factorame v. Niemcy; Z. Banaszczyk, op. cit., s. 403.

S. Rosmarin, O roszczeniach odszkodowawczych z powodu bezprawia urzędnika administracyjnego, Lwów 1933, s. 78, uw. 1. Zob. także O. Mayer, Die Entschädigungspflicht des Staates nach Billigkeitsrecht, Dresden 1904, s. 13-14 i 21. 
W ostatnich dziesięcioleciach tendencje te przybrały na sile. Są dostrzegalne również w prawie polskim. Znamiennym tego przykładem jest art. 18 ust. 5 ustawy z dnia 21 czerwca 2001 r. o ochronie praw lokatorów, mieszkaniowym zasobie gminy i o zmianie kodeksu cywilnego (t.j. Dz.U. 2019, poz. 1182). Wiele racji przemawia za trafnością tezy, iż ustawodawca w tym akcie normatywnym, odwołując się do reżimu odpowiedzialności deliktowej władz publicznych, wprowadził pewne rozwiązania systemowe z zakresu szeroko pojętego zabezpieczenia społecznego. Chodzi bowiem o zaspokojenie potrzeb mieszkaniowych relatywnie ubogich osób, wymienionych w treści art. 14 ust. 3 i 4 tej ustawy ${ }^{50}$.

Zauważa się także, że również $\mathrm{w}$ orzecznictwie TSUE reżim odpowiedzialności odszkodowawczej władz publicznych jest wykorzystywany do realizacji celów nieodpowiadających klasycznym, cywilistycznym funkcjom tej odpowiedzialności. Chodzi o traktowanie odpowiedzialności odszkodowawczej władz publicznych jako dodatkowego instrumentu wymuszającego przestrzeganie prawa unijnego. Odpowiedzialność odszkodowawcza do pewnego stopnia ma stać się więc swoistą maczugą na państwa nieimplementujące dyrektywy ${ }^{51}$. W konsekwencji dostrzega się pewne anomalie - w celu zapewnienia skuteczności prawa unijnego niektóre przypadki naruszenia prawa unijnego przez władzę publiczną państw członkowskich rodzą bowiem odpowiedzialność odszkodowawczą, podczas gdy podobne przypadki działań tej władzy nieodnoszące się jednak do prawa unijnego mogą tej odpowiedzialności nie rodzićs ${ }^{52}$. Przynajmniej teoretycznie istnieje zatem możliwość, że TSUE orzeknie, iż państwo polskie powinno taką odpowiedzialność odszkodowawczą za zanieczyszczone powietrze ponieść, gdyż tylko w taki sposób można skutecznie wymusić na państwie polskim przestrzeganie dyrektywy w sprawie czystości powietrza. Tak może się stać, gdy sąd polski, przed którym zawiśnie sprawa o odszkodowanie od państwa za zanieczyszczone powietrze, skieruje do TSUE pytania prejudycjalne (art. 267 TfUE). Zauważmy, że w ostatnich kilkudziesięciu latach wszystkie najważniejsze orzeczenia TSUE (ETS) dotyczące odpowiedzialności odszkodowawczej państw za naruszenie prawa wspólnotowego zapadły $\mathrm{w}$ wyniku wszczęcia takiej prejudycjalnej procedury. Ryzyko takie dla państwa polskiego staje się dość realne szczególnie wtedy, gdy uwzględni się fakt, iż zarówno w orzecznictwie TSUE, jak i w decyzjach Komisji Europejskiej z ostatnich lat ochrona klimatu jest coraz bardziej eksponowana, a Polska - jak zauważa E. Radecka - stała się „niechlubnym ulubieńcem Trybunału"53. Pojawia się jednak pytanie, czy taka odpowiedzial-

50 Zob. szeroko na ten temat R. Szczepaniak, Odpowiedzialność odszkodowawcza gminy, Warszawa 2018, s. 337 i n.

51 Ibidem, s. 67 i podana tam literatura oraz orzecznictwo.

52 Zob. F.G. Jacobs, Some Remarks on Community and Member State Liability [w:] Principles of Proper Conduct for Supranational, State and Private Actors in the European Union: Towards a Ius Commune, red. J. Wouters, J. Stuyck, Cambridge 2001, s. 131. 
ność miałaby wiele wspólnego z klasycznym reżimem odpowiedzialności odszkodowawczej, a przede wszystkim z „zasadami ogólnymi” odpowiedzialności pozaumownej, „wspólnymi dla prawa Państw Członkowskich”, o których mowa w art. 340 TfUE. Jednocześnie wskazane byłoby, aby TSUE doprecyzował określony w swym orzecznictwie kształt odpowiedzialności państw członkowskich za skutki naruszeń prawa wspólnotowego. Wyłaniająca się z tego orzecznictwa tzw. formuła Frankovich („Frankovich liability” lub „Frankovich doctrine”) ${ }^{54}$ nie jest bowiem jeszcze dostatecznie jasna. Wydaje się, że rozpatrywany przypadek byłby dobrą okazją ku temu, by jednak domagać się od TSUE przestrzegania w ewentualnym rozstrzygnięciu zasad, do których odwołuje się art. 340 TfUE.

\section{Zakończenie}

Niniejszy artykuł ma w gruncie rzeczy smutny wydźwięk. Do jego napisania skłoniły mnie informacje na temat wielce kontrowersyjnych, omówionych powyżej wyroków sądów rejonowych w Warszawie. Uznałem, że jako prawnik specjalizujący się w tematyce odpowiedzialności władz publicznych powinienem się do nich odnieść. W moim przekonaniu sądy nie wykazały się pogłębioną refleksją nad tymi złożonymi stanami faktycznymi. W szczególności nie wzięły pod uwagę masowej natury tych zjawisk. Nie dostrzegły również, że ich ocena prawna wymaga wyjścia poza ramy klasycznej subsumcji prawniczej oraz klasycznego mechanizmu kompensacyjnego. Podczas przygotowywania niniejszego tekstu zapoznałem się z wieloma dokumentami zawierającymi informacje na temat zanieczyszczenia powietrza w Polsce. Dane te są poruszające. Zdawałem sobie sprawę, iż stan powietrza jest zły - stanowi to przecież wiedzę powszechną. Nie przypuszczałem jednak, że jest dramatyczny. Te fakty nie zmieniły jednak mojej krytycznej oceny wskazanych orzeczeń sądowych, którą wyrobiłem sobie już przed rozpoczęciem pisania tekstu. Artykuł ten potwierdza bowiem, iż reżim odpowiedzialności odszkodowawczej nie jest panaceum na wszelkiego rodzaju błędy i zaniechania państw. Dowodzi także, iż pomimo niezaprzeczalnej ewolucji mechanizmu odpowiedzialności odszkodowawczej zaszłej na przestrzeni ponad 100 lat efektywność wypracowanego w cywilistyce mechanizmu odpowiedzialności odszkodowawczej nie jest nieograniczona i ma swoje naturalne granice. Można bowiem mówić o naturze reżimu odpowiedzialności odszkodowawczej władz publicznych. Naturę tę, którą należy respektować, determinuje zasada równości wobec ciężarów publicznych. Autor w żadnym wypadku nie neguje potrzeby podejmowania intensywnych działań w celu poprawy jakości

54 W. van Gerven, The emergence of a common European law in the area of tort law: the EU contribution [w:] Tort Liability of Public Authorities in Comparative Perspective, red. D. Fairgrieve, M. Andenas, J. Bell, 2002, s. 130. 
powietrza w Polsce. Jednak w jego ocenie użycie do realizacji tego celu reżimu odpowiedzialności władz publicznych jest wielce niefortunne.

\section{Bibliografia}

Bagińska E., Odpowiedzialność odszkodowawcza za wykonywanie władzy publicznej, Warszawa 2006.

Banaszczyk Z., Odpowiedzialność za szkody wyrządzone przy wykonywaniu władzy publicznej, Warszawa 2015.

Behnke M., Zanieczyszczenie środowiska jako naruszenie prawa do prywatności - refleksje na tle orzecznictwa Europejskiego Trybunału Praw Człowieka [w:] Prawa człowieka a ochrona środowiska. Wspólne wartości i wyzwania, red. B. Gronowska, B. Rakoczy, J. Kapelańska-Pręgowska, K. Karpus, P. Sadowski, Toruń 2018.

Bell J., Governmental Liability: Some Comparative Reflections, „InDret. Revista para el analisis del derecho" 2006, no. 322.

Bydlinski F., Kriterien und Sinn der Unterscheidung von Privatrecht und öffentlichem Recht, „Archiv für die civilistische Praxis” 1994, Band 1094.

Coleman J.L., The Economic Structure of Tort Law, „The Yale Law Journal” 1988, vol. 97.

Danwitz T. von, Die gemeinschaftsrechtliche Staatshaftung der Mitgliedstaaten, „Deutsches Verwaltungsblatt" 1997, Nr. 1.

Duguit L., Traité de droit constitutionnel, t. III, La théorie générale de leétat, Paris 1923.

Gaweł M., Prawo do życia w czystym środowisku a ochrona powietrza w kontekście zagadnienia dóbr osobistych oraz zaniechań legislacyjnych [w:] Prawne instrumenty ochrony powietrza. Wybrane zagadnienia, red. F. Nawrot, E. Radecka, Katowice 2019.

Gawlik B., Kubas A., Odpowiedzialność cywilna Skarbu Państwa - Prezydium Rady Narodowej za szkody wynikłe z braku należytej troski o zapewnienie bezpieczeństwa na terenie objętym działalnością Rady Narodowej, „Studia Cywilistyczne” 1971, t. XVII.

Gerven W. van, The emergence of a common European law in the area of tort law: the EU contribution [w:] Tort Liability of Public Authorities in Comparative Perspective, red. D. Fairgrieve, M. Andenas, J. Bell, 2002.

Gorgol A., Równowaga budżetowa $w$ świetle orzecznictwa Trybunału Konstytucyjnego, „Państwo i Prawo” 2014, z. 9.

Grzeszak T., Celebryci kontra tabloidy, czyli o nowych funkcjach zadośćuczynienia, „Zeszyty Naukowe Uniwersytetu Jagiellońskiego. Prace z Prawa Własności Intelektualnej” 2007, z. 100.

Jacobs F.G., Some Remarks on Community and Member State Liability [w:] Principles of Proper Conduct for Supranational, State and Private Actors in the European Union: Towards a Ius Commune, red. J. Wouters, J. Stuyck, Cambridge 2001.

Kasprzyk R., Bezprawność względna, „Studia Prawnicze” 1988, nr 3.

Kosik J., Zasady odpowiedzialności państwa za szkody wyrządzone przez funkcjonariuszów, Wrocław 1961. 
Kuźmicka-Sulikowska J., Zasady odpowiedzialności deliktowej w świetle nowych tendencji w ustawodawstwie polskim, Warszawa 2011.

Kwidzyński E., Ekologizm jako ideologia polityczna na przykładzie Niemiec i Francji, „Ogrody Nauk i Sztuk” 2015, nr 5, https://doi.org/10.15503/onis2015.125.132.

Laubadère A. de, Venezia J.C., Gaudemet J.C., Traité de droit administratif, t. I, Paris 1994. Łyczko P., Jakość powietrza w Polsce na tle UE, https://powietrze.malopolska.pl/baza/jakosc-powietrza-w-polsce-na-tle-unii-europejskiej [dostęp 13 września 2017 r.].

Mayer O., Die Entschädigungspflicht des Staates nach Billigkeitsrecht, Dresden 1904.

Posner R.A., Economic analysis of law, Boston-Toronto 1972.

Radecka E., Wyrok Trybunatu Sprawiedliwości Unii Europejskiej z dnia 22 lutego 2018 r. w sprawie C336/16 Komisja Europejska vs. Rzeczpospolita Polska - konsekwencje prawne [w:] Prawne instrumenty ochrony powietrza. Wybrane zagadnienia, red. F. Nawrot, E. Radecka, Katowice 2019.

Rebhahn R., Staatshaftung nach dem Recht der Europäischen Gemeinschaft, „Juristische Blätter" 1996, Nr. 12.

Rosmarin S., O roszczeniach odszkodowawczych z powodu bezprawia urzędnika administracyjnego, Lwów 1933.

Skoczylas J.J., Odpowiedzialność państwa za zaniechanie legislacyjne [w:] Czyny niedozwolone $w$ prawie polskim i prawie porównawczym, Materiały Ogólnopolskiego Zjazdu Cywilistów w Toruniu w 2011 r., red. M. Nesterowicz, Warszawa 2012.

Sokolewicz W. [w:] Konstytucja RP, t. IV, red. L. Garlicki, Warszawa 2003.

Stec P., Umowy w administracji. Studium cywilnoprawne, Warszawa 2013.

Stelmachowski A., Wstęp do teorii prawa cywilnego, Warszawa 1984.

Szczepaniak R., Odpowiedzialność odszkodowawcza gminy, Warszawa 2018.

Szczepaniak R., Odpowiedzialność odszkodowawcza jednostek samorzadu terytorialnego, Warszawa 2001.

Szczepaniak R., Zmiany $w$ drugim filarze emerytalnym $z$ perspektywy cywilistycznej, „Kwartalnik Prawa Prywatnego” 2016, z. 4.

Szpunar A., Odpowiedzialność osób zobowiązanych do nadzoru, Warszawa 1978.

Szpunar A., Odpowiedzialność Skarbu Państwa za funkcjonariuszy, Warszawa 1985.

Tofaris S., Steel S., Police liability in negligence for failure to prevent crime: time to rethink, „University of Cambridge, Faculty of Law Legal Studies Research Paper Series” 2014, no. 39, https://doi.org/10.2139/ssrn.2469532.

Trzcińska D., Sprawiedliwość ekologiczna w systemie prawa ochrony środowiska. Wartości czy wyzwania dla praw człowieka? [w:] Prawa człowieka a ochrona środowiska. Wspólne wartości i wyzwania, red. B. Gronowska, B. Rakoczy, J. Kapelańska-Pręgowska, K. Karpus, P. Sadowski, Toruń 2018.

Wróbel P. ks., Postulat sprawiedliwości społecznej a idea sprawiedliwości, „Studia Socialia Cracoviensia" 2013, nr 1, https://doi.org/10.15633/ssc.434. 